\title{
Species diversity of sandflies (Diptera: Psychodidae) during different seasons and in different environments in the district of Taquaruçú, state of Tocantins, Brazil
}

\author{
Tâmara Oliveira Machado', Marcos Antônio Lima Bragança², \\ Muzenilha Lima Carvalho3 ${ }^{3}$, José Dilermando Andrade Filho ${ }^{4}++$ \\ ${ }^{1}$ Setor de Controle Vetorial, Gerência de Vigilância em Saúde, Secretaria Municipal de Saúde, Palmas, TO, Brasil \\ ${ }^{2}$ Curso de Ciências Biológicas, Universidade Federal do Tocantins, Porto Nacional, TO, Brasil ${ }^{3}$ Núcleo de Entomologia, \\ Secretaria Estadual de Saúde, Palmas, TO, Brasil ${ }^{4}$ Coleção de Flebotomíneos, Centro de Referência Nacional e \\ Internacional para Flebotomíneos, Centro de Pequisas René Rachou-Fiocruz, Belo Horizonte, MG, Brasil
}

Phlebotomine sandflies are the vectors for the protozoan parasites that cause leishmaniasis. The present study investigated the species composition of sandfly fauna in the rural district of Taquaruçu, municipality of Palmas, state of Tocantins, Brazil and compared the diversity of species among intradomicile, peridomicile and forest environments during the dry and rainy seasons. Sandflies were collected using CDC light traps over the course of three months during the dry and rainy seasons. A total of 767 specimens were captured, belonging to different 32 species. The most abundant species were Micropygomyia goiana (Martins, Falcão \& Silva), Sciopemyia sordellii (Shannon \& Del Ponte), Evandromyia carmelinoi (Ryan Fraiha, Lainson \& Shaw), Evandromyia termitophila (Martins, Falcão \& Silva), Nyssomyia whitmani (Antunes \& Coutinho) and Lutzomyia longipalpis (Lutz \& Neiva). The highest species diversity (30) and the greatest percentage of specimens (78.3\%) were obtained during the rainy season. During the dry season, the species richness and abundance were greater in domestic environments. However, during the rainy season, the forest displayed the highest species richness and the domestic environment exhibited the greatest species abundance. Several important vector species are reported in this study.

Key words: Evandromyia - leishmaniasis - Phlebotominae - Psathyromyia - Psychodopygus

The phlebotomine sandflies belong to the subfamily Phlebotominae of the order Diptera. The females of most species are hematophagous and are responsible for the transmission of the protozoan parasites that cause visceral leishmaniasis (VL) and American cutaneous leishmaniasis (ACL) (Forattini 1973).

In 1988, the state of Tocantins (TO) was created by the Federal Constitution of Brazil. The creation of this state caused rapid socio-economic growth in this region that was often unplanned. Consequently, this rapid growth impacted the environment and may have led to public health problems in the state. For example, leishmaniasis has become a problem because sandflies adapt relatively easily to environmental changes and their presence is now common in urban and rural areas of Brazil (Leonardo \& Rebêlo 2004, Nunes et al. 2008).

It is important to understand the species diversity and behaviour of sandflies in affected areas and during different seasons. For instance, if conditions are favourable for sandflies, they can initiate a new cycle of leishmaniasis that endangers the residents in these regions. For these reasons and because there is little information

+ Corresponding author: jandrade@cpqrr.fiocruz.br

Received 15 March 2012

Accepted 16 May 2012 about sandflies in TO, particularly in the rural district of Taquaruçu, this study aimed to identify the species composition of sandflies in this locality. In addition, the diversity of these insects was compared among intradomicile, peridomicile and forest environments during the dry and rainy seasons. These data will help support future actions to control leishmaniasis in this area.

The district of Taquaruçu is located in the Environmental Protection Area of Serra do Lajeado between the coordinates $10^{\circ} 18^{\prime} \mathrm{S} 48^{\circ} 09^{\prime} \mathrm{W}, 32 \mathrm{~km}$ from Palmas. The average annual rainfall in this region is $1.600 \mathrm{~mm}$, with a distinct dry season occurring from April-September and a separate wet season from October-March (AMATP 2000). Since 2004, there has been no record of VL in this region and only three cases of ACL have been confirmed (SINAN 2012). Sampling sites located $4.4 \mathrm{~km}$ apart (site 1 and site 2) were selected for this study. At each sampling site, sandflies were collected in the following three environments: intradomicile (bedrooms), peridomicile (chicken coops) and extradomicile (forest). For sampling site 1, the edge of the forest was $20 \mathrm{~m}$ from the house and for sampling site 2 the edge of the forest was $10 \mathrm{~m}$ from the house.

Three CDC light traps were installed in each environment between 03:00 pm-05:00 pm and removed on the following day between 07:00 am-09:00 am. This collection procedure was performed over three consecutive nights in each month and collections were performed three times during the dry season (June-August 2007) and three times during the rainy season (November 
2007-January 2008). Identification of the collected sandfly species was performed according to the classification of Galati (2003) and the abbreviation of generic names followed the system of Marcondes (2007).

The statistical Past program version 1.8 (Hammer et al. 2001) was used to analyse the diversity (richness and equitability) and similarity of the collected sandflies. To quantify diversity, the Shannon-Wiener diversity index (H') was calculated as follows:

$$
\mathrm{H}^{\prime}=-\sum \mathrm{S}_{\mathrm{i}=1} \mathrm{p}_{\mathrm{i}} \ln \mathrm{p}_{\mathrm{i}}
$$

where $\mathrm{p}=$ the frequency of species, $\ln =$ natural $\log$ and $\mathrm{S}=$ species richness. For comparisons of diversity between the dry and rainy seasons, the intradomestic, peridomestic and forest environments and the months of each period we used t tests at a 5\% probability. The Pielou evenness index $(\mathrm{J})$ was obtained using the formula $J=H^{\prime} / 1 n S$, with $S$ being the number of species per site. The Jaccard similarity index (cj) was used for cluster analysis of the Jaccard distance according to the following equation:

$$
(c j)=c /(a+b+c)
$$

where $a=$ species found at site "a", $b=$ species found in sample " $b$ " and $c=$ species found in both samples ("a" and "b"). Abundance analysis was performed using the chi-squared test with the Past program version 1.8.

A total of 767 phlebotomine sandflies were collected belonging to 32 different species (Table). The most highly represented subtribe was Lutzomyiina with 14 species identified, followed by Psychodopygina, with 11 species identified, Sergentomyiina, with six species identified and Brumptomyiina, with one species identified. One morphospecies specimen could not be identified because only this single female of the morphospecies was found, although it may be either Psychodopygus wellcomei (Fraiha, Shaw \& Lainson 1971) or Psychodopygus complexa (Mangabeira 1941). The most abundant species are shown in Table.

The average value of the H' was 2.54 and that of the $\mathrm{J}$ evenness index was 0.73 . The species richness was highest in the rainy season; however, 18 species were common to both periods of the year. Two species were exclusive to the dry season and 12 species were found only in the rainy season (Table). The cj between the rainy and dry seasons was 0.56 .

Climate data for the district of Taquaruçu during the months in which the sandflies were captured showed that in the dry season the average rainfall was $0.0 \mathrm{~mm}$, the temperature was $26.7^{\circ} \mathrm{C}$ and the relative humidity ( $\left.\mathrm{RH}\right)$ was $55.4 \%$. In the rainy season, the average rainfall was $47.6 \mathrm{~mm}$, the temperature was $26.8^{\circ} \mathrm{C}$ and the $\mathrm{RH}$ was $70.2 \%$. The abundance of sandflies in the dry season $(22 \%)$ was lower than in the rainy season $(78 \%)$ and this difference was significant $(\chi 2=245.6, p<0.01)$. There was no significant difference in the $H^{\prime}$ between the two periods of the year $(t=0.71, p=0.47)$. The $J$ for the dry season was 0.81 and for the rainy season was 0.72 .

The greatest species richness during the rainy season occurred in the forest (22 species), followed by the peridomicile (20 species) and intradomicile (19 species) areas. The species distribution by environment is shown in Table. The cluster similarity analysis for both seasons indicated a greater similarity between the peridomicile and forest areas than with the intradomicile area.

The intradomicile areas presented the greatest abundance of sandflies during the dry period $(42.8 \%)$, followed by the peridomicile (42.2\%) and forest (15.1\%) locations. During the rainy season, the peridomicile areas showed the highest percentage of sandflies $(41.5 \%)$, followed by the intradomicile (32\%) and forest (26.5\%) locations.

All $t$ test comparisons of H' values between the different environments during the dry season were nonsignificant $(p>0.05)$. However, during the rainy season, this index was higher in the peridomicile than the intradomicile area $(t=-2.75, p<0.05)$ and in the forest compared to the intradomicile $(t=-6.22, p<0.05)$ and peridomicile areas $(t=-4.15, p<0.05)$. The differences in H' values for the same environment between different periods of the year were not significant for the intradomicile and peridomicile areas $(p>0.05)$; however, this difference was significantly higher in the forest during the rainy season $(\mathrm{t}=-2.28, \mathrm{p}<0.05)$.

The values of the $\mathrm{J}$ for the dry season were $0.75,0.87$ and 0.94 for the intradomicile, peridomicile and forest environments, respectively. During the rainy season, this index decreased to $0.66,0.75$ and 0.86 for the intradomicile, peridomicile and forest environments, respectively.

The predominance of Lutzomyiina can be explained by the presence of a large number of species of the genus Evandromyia. This group of sandflies is very common in the savannah (cerrado) regions of Brazil. Saraiva et al. (2008) found that $26.3 \%$ of the sandflies in the state of Minas Gerais were from the genus Evandromyia. Another frequently identified genus was Psathyromyia, represented by six species $(18.8 \%)$. This genus is found in preservation areas, particularly forest environments (Almeida et al. 2010, Margonari et al. 2010).

The species richness of the 32 sandfly species observed in Taquaruçu was consistent with that found by Andrade Filho et al. (2001). Vilela et al. (2011) observed greater species richness, with 48 identified species, whereas Lustosa et al. (1986) found only 14 species. The species richness observed in this study was greater during the rainy season than during the dry season. This pattern has also been observed in several studies performed in the Northeast region of Brazil (Barros et al. 2000, Martin \& Rebêlo 2006). However, Rebêlo et al. (2001) and Marinho et al. (2008) observed more species during the dry season in the state of Maranhão (MA). During the dry season, the greatest species richness was found in the intradomicile environment, followed by the peridomicile and the forest environments. This may be because at this time of year, the humidity is very low and fires are frequent, making the home environment more favourable for some species of sandflies, such as Bichromomyia flaviscutellata (Mangabeira 1942). Martin and Rebêlo (2006) obtained different results in MA, with the highest species richness being observed in the peridomicile environment, followed by the forest and intradomicile environments. 
During the rainy season, the greatest number of species was observed in the forest, followed by the peridomicile and the intradomicile areas. The highest similarity was found between the peridomicile and forest areas, most likely because the peridomicile areas were close to the forest, which may have facilitated the movement of many species between these environments.

A greater abundance of sandflies was observed in the home environment in both intra and peridomicile areas for both periods studied, suggesting an increased risk of leishmaniasis transmission to humans and their pets dur- ing these periods. de Souza et al. (2004) found an increase in the number of human cases of ACL and AVL after an increase in sandfly numbers after rain. The higher density of sandflies in the home compared to natural environments, such as forests, suggests that the presence of domestic animals and humans can cause some species to significantly increase in number in human environments. The increases in population density or abundance around homes show the degree of adaptation that sandflies have undergone associated with increasing anthropogenic activity (Missawa \& Lima 2006, Saraiva et al. 2011) and

TABLE

Species of sandflies collected with CDC light trap in the district of Taquaruçu, Palmas, Tocantins, in the dry (June-August 2007) and rainy season (November 2007 and January 2008)

\begin{tabular}{|c|c|c|c|c|c|c|c|c|c|}
\hline \multirow[b]{2}{*}{ Species } & \multirow[b]{2}{*}{$\mathrm{n}$} & \multicolumn{3}{|c|}{ Dry season environment } & \multirow[b]{2}{*}{$\mathrm{n}$} & \multicolumn{3}{|c|}{ Rainy season environment } & \multirow[b]{2}{*}{ Total } \\
\hline & & Intradomicile & Peridomicile & Forest & & Intradomicile & Peridomicile & Forest & \\
\hline Micropygomyia goiana & 32 & 28.3 & 14.5 & 7.8 & 166 & 43.8 & 24.5 & 13.2 & 198 \\
\hline Siopemyia sordellii & 10 & 2.8 & 7.2 & 11.5 & 95 & 10.4 & 22.5 & 12.0 & 105 \\
\hline Evandromyia carmelinoi & 17 & 2.8 & 14.5 & 19.2 & 71 & 7.3 & 12.9 & 15.8 & 88 \\
\hline Evandromyia termitophila & 6 & 2.8 & 4.4 & 3.8 & 67 & 14.1 & 10.1 & 9.4 & 73 \\
\hline Nyssomyia whitmani & 32 & 18.3 & 24.6 & 7.8 & 39 & 8.3 & 4.4 & 7.6 & 71 \\
\hline Lutzomyia longipalpis & 24 & 24 & 7.2 & 7.8 & 12 & 3.7 & 2 & 0 & 36 \\
\hline Micropygomyia micropyga & 0 & 0 & 0 & 0 & 24 & 1.6 & 8 & 0.6 & 24 \\
\hline Evandromyia evandroi & 11 & 5.6 & 8.7 & 3.8 & 9 & 1 & 1.2 & 2.5 & 20 \\
\hline Pressatia choti & 3 & 1.4 & 1.5 & 3.8 & 15 & 1 & 0.8 & 6.9 & 18 \\
\hline Psathyromyia hermanlenti & 7 & 1.4 & 4.4 & 11.5 & 10 & 0 & 0.4 & 5.7 & 17 \\
\hline Evandromyia lenti & 6 & 1.4 & 5.8 & 3.8 & 11 & 1.6 & 2.4 & 1.3 & 17 \\
\hline Micropygomyia longipennis & 3 & 1.4 & 1.5 & 3.8 & 11 & 2.1 & 2.4 & 0.6 & 14 \\
\hline Psathyromyia runoides & 2 & 0 & 0 & 7.8 & 10 & 0 & 2.4 & 2.5 & 12 \\
\hline Psathyromyia aragaoi & 2 & 0 & 1.5 & 3.8 & 9 & 0 & 1.6 & 3.1 & 11 \\
\hline Evandromyia walkeri & 0 & 0 & 0 & 0 & 9 & 0.5 & 1.2 & 3.1 & 9 \\
\hline Psathyromyia brasiliensis & 0 & 0 & 0 & 0 & 8 & 0 & 0.4 & 5 & 9 \\
\hline Bichromomyia flaviscutellata & 1 & 1.4 & 0 & 0 & 6 & 0 & 0 & 3.8 & 7 \\
\hline Evandromyia sallesi & 1 & 1.4 & 0 & 0 & 5 & 0 & 1.2 & 1.3 & 6 \\
\hline Micropygomyia echinatopharynx & 3 & 1.4 & 2.9 & 0 & 2 & 0.5 & 0.4 & 0 & 5 \\
\hline Evandromyia teratodes & 1 & 0 & 0 & 3.8 & 2 & 0.5 & 0 & 0.6 & 3 \\
\hline Evandromyia saulensis & 0 & 0 & 0 & 0 & 3 & 0 & 0 & 1.9 & 3 \\
\hline Micropygomyia oswaldoi & 3 & 4.2 & 0 & 0 & 0 & 0 & 0 & 0 & 3 \\
\hline Psathyromyia punctigeniculata & 0 & 0 & 0 & 0 & 3 & 1.6 & 0 & 0 & 3 \\
\hline Micropygomyia rorotaensis & 0 & 0 & 0 & 0 & 3 & 0 & 0 & 1.9 & 3 \\
\hline Pintomyia christenseni & 1 & 0 & 1.5 & 0 & 1 & 0 & 0 & 0.6 & 2 \\
\hline Martinsmyia oliveirai & 0 & 0 & 0 & 0 & 2 & 0 & 0.8 & 0 & 2 \\
\hline Psychodopygus davisi & 0 & 0 & 0 & 0 & 2 & 0.5 & 0 & 0.6 & 2 \\
\hline Evandromyia bacula & 1 & 1.4 & 0 & 0 & 0 & 0 & 0 & 0 & 1 \\
\hline Psychodopygus complexa/welcomei & 0 & 0 & 0 & 0 & 1 & 0 & 0.4 & 0 & 1 \\
\hline Evandromyia corumbaensis & 0 & 0 & 0 & 0 & 1 & 0.5 & 0 & 0 & 1 \\
\hline Psathyromyia lutziana & 0 & 0 & 0 & 0 & 1 & 0.5 & 0 & 0 & 1 \\
\hline Brumptomyia brumpti & 0 & 0 & 0 & 0 & 1 & 0.5 & 0 & 0 & 1 \\
\hline$\%$ & - & 100 & 100 & 100 & 100 & 100 & 100 & 100 & 100 \\
\hline Total & 166 & 71 & 69 & 26 & 601 & 192 & 250 & 159 & 767 \\
\hline Species total & 20 & 16 & 14 & 14 & 30 & 19 & 20 & 22 & 32 \\
\hline
\end{tabular}


these increases may be associated with cases of leishmaniasis (Rebêlo et al. 2001, de Souza et al. 2004).

Slightly more Nyssomyia whitmani specimens were captured in the home during the rainy season. This species is a vector of Leishmania braziliensis in some regions of Brazil (Luz et al. 2000, Saraiva et al. 2011). The preference of $\mathrm{Ny}$. whitmani for domestic environments suggests that this species is well adapted to these areas in Taquaruçu and may be involved in the transmission of leishmaniasis, as previously observed by Martin and Rebêlo (2006) and Mayo et al. (1998) in other areas.

Lutzomyia longipalpis is the main vector of Leishmania infantum chagasi (Gontijo \& Melo 2004) and has been reported in all regions of Brazil and in many countries of South America (Souza et al. 2009, Salomón et al. 2011). It is the most frequent and perhaps the best adapted species with respect to living with humans and domestic animals (Rebêlo et al. 1999). This species was found during both the dry and wet seasons and showed a preference for the dry period and household areas, particularly intradomicile areas. In Taquaruçu, the domestic environment and dry period appear to be more favourable for the transmission of AVL. This is important for epidemiological surveillance because of the risk of introduction of AVL to the district of Taquaruçu.

Other species were observed in addition to Ny. whitmani and Lu. longipalpis, though at lower frequencies; however, they included a number of important vectors for leishmaniasis, such as Psychodopygus davisi, Psychodopygus complexus/Ps. wellcomei and Bi.flaviscutellata. Bi. flaviscutellata is a zoophilic species and is considered to represent the vector of Leishmania amazonensis (Shaw 1972). The occurrence of this species in intradomicile areas is worrisome because according Rebêlo et al. (1999), it appears that this species is adapting not only to secondary forests, but also to the home environment.

Evandromyia corumbaensis and Evandromyia sallesi belong to the cortelezzii complex, along with Evandromyia spelunca Carvalho, Sanguinette, Brazil \& Andrade Filho 2011 and Evandromyia cortelezzii (Brèthes 1923) (Carvalho et al. 2011). This complex has a wide geographical distribution in Brazil (Carvalho et al. 2009) and two species, Evandromyia sallesi and Ev. cortelezzii, were recently found to be naturally infected with Leishmania (Carvalho et al. 2008, Saraiva et al. 2009).

Ps. wellcomei is present in the Amazon in Pará and in the forest zone of Pernambuco (Ward et al. 1973, Dantas-Torres et al. 2010). This sandfly is responsible for the transmission of L. braziliensis (Ryan et al. 1987). The distribution of Ps. complexus is restricted to the Amazon Basin and MA (Young \& Duncan 1994, Martin \& Rebêlo 2006). In this study, the only specimen of Ps. wellcomei/ Ps. complexus collected could not be further identified because no males were found and females of these species are indistinguishable from each other (Young \& Duncan 1994). Both species may be involved in the transmission of cutaneous leishmaniasis in northern Brazil (Souza et al. 1996). Despite this taxonomic uncertainty, detection of $P S$. wellcomei or Ps. complexus can now be reported in TO.

The highest value of H' was observed in the forest, followed by the peridomicile and intradomicile areas during the rainy season. This finding differs from those of Martin and Rebêlo (2006), who found greater diversity in intradomicile areas, followed by forest and peridomicile areas. The increase in the number of species in the forest during the rainy season was most likely due to greater structural variety with regard to the available habitats and ecological niches (Ricklefs 1996).

The dry season was characterised by a more even distribution of sandflies among the environments than the rainy season, consistent with the findings of Barros et al. (2000). These findings indicate that individuals are more evenly distributed in the dry forest environment than in the other environments studied.

Among studies previously conducted in TO, 58 species of sandflies had been reported (Lustosa et al. 1986, Andrade Filho et al. 2001, Carvalho et al. 2010, Vilela et al. 2011). Of the species collected, four (Martinsmyia oliveirai, Psathyromyia runoides, Pressatia choti and Ps. wellcomei/Ps. complexa) were first observed in TO. Thus, with the information presented here, the number of species of sandflies reported in TO is increased to a total of 62 .

\section{ACKNOWLEDGEMENTS}

To Dr Joenes Muzii Pelucio (UFT) and Dr Rafael José de Oliveira (UFT), who assisted with the statistical analysis, to Lusy Disney Gomes de Andrade Almeida and colleagues of the Entomology Laboratory of the Center for Zoonosis Control (TO), for ideas, support and loan of materials, and the biologist Perpétua Bezerra Sales (SESAU/TO), by helping in the identification of some specimens.

\section{REFERENCES}

Almeida PS, Nascimento JC, Ferreira AD, Minzão LD, Portes F, Miranda AM, Faccenda O, Andrade Filho JD 2010. Espécies de flebotomíneos (Diptera, Psychodidae) coletadas em ambiente urbano em municípios com transmissão de leishmaniose visceral do estado de Mato Grosso do Sul, Brasil. Rev Bras Ent 54: 304-310.

AMATP - Agência de Meio Ambiente e Turismo de Palmas 2000. Diagnóstico turístico do distrito de Taquaruçú, Palmas, Tocantins, AMATP, Palmas, 15 pp.

Andrade Filho JD, Valente MB, Andrade WA, Brazil RP, Falcão AL 2001. Flebotomíneos do estado de Tocantins, Brasil (Diptera: Psychodidae). Rev Soc Bras Med Trop 34: 323-329.

Barros VL, Rebêlo JMM, SilvA FS 2000. Flebotomíneos (Diptera, Psychodidae) de capoeira do município do Paço do Lumiar, estado do Maranhão, Brasil. Área endêmica de leishmanioses. Cad Saude Publica 16: 265-270.

Carvalho GML, Andrade Filho JD, Falcão AL, Lima ACVMR, Gontijo CMF 2008. Naturally infected Lutzomyia sand flies in a Leishmania-endemic area of Brazil. Vector Borne Zoonotic Dis 8: 407-414.

Carvalho GML, Brazil RP, Falcão AL, Andrade Filho JD 2009. Distribuição geográfica do complexo cortelezzii (Diptera: Psychodidae: Phlebotominae) no Brasil. Neotrop Entomol 38: 876-879.

Carvalho GM de L, Brazil RP, Sanguinette C de C, Andrade Filho JD 2010. Description of a new phlebotomine species, Martinsmyia reginae sp. nov. (Diptera: Psychodidae: Phlebotominae) from a cave in the state of Tocantins, Brazil. Mem Inst Oswaldo Cruz 105: 336-340.

Carvalho GML, Sanguinette CC, Brazil RP, Andrade Filho JD 2011. Description of Evandromyia spelunca, a new phlebotomine species of the cortelezzii complex, from a cave in Minas Gerais state, Brazil (Diptera: Psychodidae: Phlebotominae). Parasites \& Vectors 4: 158 . 
Dantas-Torres F, Andrade AJ, Tenório KER, Andrade Filho JD, Balbino VQ, Brandão-Filho SP 2010. Phlebotomine sand flies (Diptera: Psychodidae: Phlebotominae) in the state of Pernambuco Rev Soc Bras Med Trop 43: 733-736.

de Souza CM, Pessanha JE, Barata RA, Monteiro EM, Costa DC, Dias ES 2004. Study on phlebotomine sand fly (Diptera: Psychodidae) fauna in Belo Horizonte, state of Minas Gerais, Brazil. Mem Inst Oswaldo Cruz 99: 795-803.

Forattini OP 1973. Entomologia médica. Psychodidae, Phlebotominae, Leishmaniose, Bartonelose, Vol. IV, Edgard Blucher, São Paulo, 658 pp.

Galati EAB 2003. Morfologia e taxonomia. Classificação de Phlebotominae. In EF Rangel, R Lainson, Flebotomíneos do Brasil, Editora Fiocruz, Rio de Janeiro, p. 23-52.

Gontijo CMF, Melo MN 2004. Leishmaniose visceral no Brasil: quadro atual, desafios e perspectivas. Rev Bras Epidemiol 7: 338-349.

Hammer Ø, Harper DAT, Ryan PD 2001. PAST: Paleontological Statistics Software Package for Education and Data Analysis. Available from: palaeo-electronica.org/2001-1/past/issue1-01.htm.

Leonardo FS, Rebêlo JMM 2004. A periurbanização de Lutzomyia whitmani em área de foco de leishmaniose cutânea no estado do Maranhão, Brasil. Rev Soc Bras Med Trop 37: 282-284.

Lustosa ES, Naves HAM, Carvalho MESD, Barbosa W 1986. Contribuição para o conhecimento da fauna flebotomínica do estado de Goiás - 1984-1985. Nota prévia I. Rev Patol Trop 15: 7-11.

Luz E, Membrive N, Castro EA, Dereure J, Pratlong F, Dedet JA, Pandey A, Thomaz-Soccol V 2000. Lutzomyia whitmani (Diptera: Psychodidae) as vector of Leishmania (V.) braziliensis in Paraná state, southern Brazil. Ann Trop Med Parasitol 94: 623-631.

Marcondes CB 2007. A proposal of generic and subgeneric abbreviations for Phlebotomine sand flies (Diptera: Psychodidae: Phlebotominae) of the world. Entomol News 118: 351-356.

Margonari C, Soares RP, Andrade Filho JD, Xavier DC, Saraiva L, Fonseca AL, Silva RA, Oliveira ME, Borges EC, Sanguinette CC, Melo MN 2010. Phlebotomine sand flies (Diptera: Psychodidae) and Leishmania infection in Gafanhoto Park, Divinópolis, Brazil. J Med Entomol 47: 1212-1219.

Marinho MR, Silva, RF, Vasconcelos GC, Azevedo PCB, Moraes JLP, Rebêlo JMM 2008. Flebotomíneos (Diptera, Psychodidae) em reservas florestais da área metropolitana de São Luís, Maranhão, Brasil. Rev Bras Entomol: 52: 112-116.

Martin AMCB, Rebêlo JMM 2006. Dinâmica espaço-temporal de flebotomíneos (Diptera, Psychodidae) do município de Santa Quitéria, área de cerrado do estado do Maranhão, Brasil. Iheringia 96: 283-288.

Mayo RC, Casanova C, Mascarini LM, Pignatti MG, Rangel O, Galati EAB, Wanderley DMV, Corrêa FMA 1998. Sand flies (Diptera, Psychodidae, Phlebotominae) of the American cutaneous leishmaniasis transmission area in the southeastern region of the São Paulo state, Brazil. Rev Soc Bras Med Trop 31: 339-345.

Missawa NA, Lima GBM 2006. Spatial distribution of Lutzomyia longipalpis (Lutz \& Neiva, 1912) and Lutzomyia cruzi (Mangabeira, 1938) in the state of Mato Grosso. Rev Soc Bras Med Trop 39: $337-340$.

Nunes VLB, Galati EAB, Cardozo C, Rocca MEG, Andrade ARO, Santos MFC, Aquino RB, Rosa D 2008. Estudo de flebotomíneos (Diptera, Psychodidae) em área urbana do município de Bonito, Mato Grosso do Sul, Brasil. Rev Bras Entomol 52: 446-451.

Rebêlo JMM, Araújo JAC, Carvalho ML, Barros VLP, Silva FS, Oliveira ST 1999. Flebótomos (Diptera, Phlebotominae) da Ilha de
São Luis, zona do Golfão Maranhense, Brasil. Rev Soc Bras Med Trop 32: 247-253.

Rebêlo JMM, Oliveira ST, Silva FS, Barros VLL, Costa JML 2001. Sand flies (Diptera: Psychodidae) of the Amazônia of Maranhão. $\mathrm{V}$. Seasonal occurrence in ancient colonization area and endemic for cutaneous leishmaniasis. Rev Bras Biol 61: 107-115.

Ricklefs R 1996. A economia da natureza, 3rd ed., Guanabara Koogan, Rio de Janeiro, $470 \mathrm{pp}$.

Ryan L, Lainson R, Shaw JJ 1987. Leishmaniasis in Brazil. XXIV. Natural flagellate infections of sand flies (Diptera: Psychodidae) in Pará state, with particular reference to the role of Psychodopygus wellcomei as the vector of Leishmania braziliensis braziliensis in the Serra dos Carajás. Trans R Soc Trop Med Hyg 81: 353-359.

Salomón OD, Basmajdian Y, Fernández MS, Santini MS 2011. Lutzomyia longipalpis in Uruguay: the first report and the potential of visceral leishmaniasis transmission. Mem Inst Oswaldo Cruz 106: 381-382.

Saraiva L, Andrade Filho JD, Falcão AL, Carvalho DAA, Souza CM, Freitas CR, Lopes CRG, Moreno EC, Melo MN 2011. Phlebotominae fauna (Diptera: Psychodidae) in an urban district of Belo Horizonte, Brazil, endemic for visceral leishmaniasis: characterization of favoured locations as determined by spatial analysis. Acta Tropica 117: 137-145.

Saraiva L, Carvalho GML, Gontijo CMF, Quaresma PF, Lima ACVMR, Falcão AL, Andrade Filho JD 2009. Natural infection of Lutzomyia neivai and Lutzomyia sallesi (Diptera: Psychodidae) by Leishmania infantum chagasi in Brazil. J Med Entomol 46: 1159-1163.

Saraiva L, Carvalho GM de L, Sanguinette C de C, de Carvalho DAA, Falcão AL, Andrade Filho JD 2008. Sandflies (Diptera: Psychodidae: Phlebotominae) collected on the banks of the Velhas River in the state of Minas Gerais, Brazil. Mem Inst Oswaldo Cruz 103: 843-846.

Shaw JJ 1972. Leishmaniasis in Brazil. VI. Observations on the seasonal types of forest and its relationship to enzootic rodent leishmaniasis (Leishmania mexicana amazonensis). Trans $R$ Soc Trop Med Hyg 39: 261-266.

SINAN - Sistema de Informação de Agravos de Notificação 2012. [database on the Internet]. [cited 24 Jan 2012]. Available from: saude.gov.br/sinanweb.

Souza AA, Ishikawa E, Braga R, Silveira F, Lainson R, Shaw J 1996. Psychodopygus complexus, a new vector of Leishmania braziliensis to humans in Pará state, Brazil. Trans R Soc Trop Med Hyg 90: 112-113.

Souza GD, dos Santos E, Andrade Filho JD 2009. The first report of the main vector of visceral leishmaniasis in America, Lutzomyia longipalpis (Lutz \& Neiva) (Diptera: Psychodidae: Phlebotominae), in the state of Rio Grande do Sul, Brazil. Mem Inst Oswaldo Cruz 104: 1181-1182.

Vilela ML, Azevedo CG, Carvalho BM, Rangel EF 2011. Phlebotomine fauna (Diptera: Psychodidae) and putative vectors of leishmaniasis in impacted area by Hydoreletric Plant, state of Tocantins, Brazil. PLoS ONE 6: e27721.

Ward RD, Shaw JJ, Lainson R, Fraiha H 1973. Leishmaniasis in Brazil: VIII. Observations on the phlebotomine fauna of an area highly endemic for cutaneous leishmaniasis in the Serra dos Carajas, Pará state. Trans R Soc Trop Med Hyg 67: 174-183.

Young DG, Duncan MA 1994. Guide to the Identification and geographic distribucion of Lutzomyia sand files in México, the West Indies, Central and South America (Diptera: Psychodidae), Memoirs of the American Entomological Institute, Florida, 881 pp. 